\title{
OČEKIVANJA O FILIJALNOJ BRIZI U STARIJOJ DOBI IZ PERSPEKTIVE ODRASLE DJECE I RODITELJA
}

Izvorni znanstveni članak

Primljeno: ožujak, 2019.

Prihvaćeno: svibanj, 2019.

UDK 316.356.2-053.8-053.9

DOI 10.3935/ljsr.v26i2.288

Katarina Banov ${ }^{1}$

orcid.org/0000-0003-1703-1404

Sanja Smojver-Ažić ${ }^{2}$

orcid.org/0000-0002-4389-6463

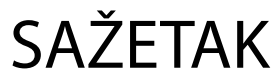

Sveučilište u Rijeci

Filozofski fakultet

Odsjek za psihologiju

Međunaraštajna filijalna solidarnost, odnosno pružanje praktične, emocionalne ili zdravstvene pomoći roditelju, dominantan je oblik skrbi za starije. Roditelji i odrasla djeca mogu imati različite stavove o odgovornosti djece u zbrinjavanju starijih roditelja. Iako su za starije osobe i njihovu djecu sigurnost $i$ očuvanje zdravlja roditelja vrlo važni, potreba za autonomijom i održavanjem dugogodišnje kvalitete odnosa može biti razlogom za preferenciju izvanobiteljskih oblika skrbi. Kod osoba koje još nisu iskusile nagli porast roditeljeve potrebe za brigom moguće je istraživanje očekivanja o obliku buduće brige za starije roditelje što predstavlja i vrijedan izvor informacija za planiranje intervencija. Cilj istraživanja bio je opisati očekivanja filijalne brige na dva nezavisna uzorka: 234 osobe u ulozi odrasle djece, mogućih pružatelja skrbi 152 starije osobe u ulozi roditelja, potencijalnih primatelja skrbi. Primjenom "Ljestvice očekivanja o filijalnoj brizi«, konstruirane za potrebe ovog istraživanja, pronađene su razlike u izraženosti očekivanja različitih ponašanja filijalne solidarnosti kao i organizacije smještaja za starijeg roditelja. Značajne razlike u očekivanjima budućeg primanja ili pružanja filijalne brige pronađene su ovisno o nekim sociodemografskim obilježjima - spolu mogućeg pružatelja brige, broju maloljetne djece te

Ključne riječi:

ljestvica procjene očekivanja o brizi, međugeneracijska solidarnost, filijalna skrb. 
udaljenosti mjesta stanovanja od roditelja. Prikazane su implikacije za istraživanja i primjenu u praksi.

\section{UVOD}

Briga za roditelje u starosti, koju nazivamo filijalnom brigom, normativan je zadatak odrasle djece. Potreba za povećanom socijalnom podrškom kod nekih se starijih osoba javlja postupno, dok se kod drugih zdravstveno stanje naglo pogoršava, te se tako i skrb odrasle djece aktivira različitom brzinom. U Hrvatskoj raste udio starog stanovništva, s posebnim ubrzanjem u skupini starijih od 85 godina, pri čemu se 46,56\% osoba starijih od 65 izjašnjava o teškoćama u obavljanju svakodnevnih aktivnosti i smanjenoj pokretljivosti (Puljiz, 2016.). U Hrvatskoj je 2011. godine u samačkom kućanstvu koje predstavlja rizik od siromaštva i osamljenosti živjelo 24,23\% osoba starijih od 65 godina (Bađun, 2015.). Samačko stanovanje starijih sve je raširenije, dok se višegeneracijska kućanstva zadržavaju uglavnom u mediteranskim zemljama Europe. Izvješće Europske komisije (European Commission, 2015.) navodi kako je u Hrvatskoj obiteljska skrb za starije učestalija od prosjeka Unije. Ograničenja formalnog sustava skrbi i financijski teret koji predstavlja za korisnike dio su razloga zbog kojih se obitelji odlučuju na neformalno zbrinjavanje svojih starijih članova, no dostupnost izvora podrške starijima razlikuje se u pojedinim regijama u Hrvatskoj (Petrak, Despot-Lučanin i Lučanin, 2006.; Podgorelec i Klempić, 2007.; Žganec, Rusac i Laklija, 2007.). Analize reformi na području sustava skrbi za starije u Hrvatskoj (Dobrotić, 2016.) pokazuju kako potreba za programima pomoći i njege u kući brzo raste dok je dostupnost sve manja. Tržište profitnih pružatelja usluga nastavlja se razvijati, no obvezu skrbi i dalje primarno nose krajnji korisnici, odnosno obitelji. Navedeni podaci oslikavaju kontekst u kojemu se pojavljuje potreba starijih osoba za filijalnom brigom.

Demografska struktura skrbnika u Republici Hrvatskoj prvi put je istražena u sklopu projekta SHARE - »/straživanju o zdravlju, starenju i umirovljenju u Europi« (Strmota, 2017.). Kao najčešći pružatelji pomoći uz supružnike, navedena su odrasla djeca, a potom osobe koje nisu članovi obitelji poput susjeda ili prijatelja. Pomoć češće primaju osobe slabijeg zdravstvenog stanja, dok spol ili obrazovanje nisu bili prediktori primljene pomoći. Istraživanja pokazuju kako su djeca oba spola uključena u pružanje brige starijim roditeljima, razlikujući pritom oblike ponašanja brige koju pružaju sinovi i kćeri: materijalna potpora češće je tražena od sinova, dok su kćeri za roditelje prvi izbor u potrebi njege zdravlja i emocionalne potpore (lkkink, van Tilburg i Knipscheer, 1999.; Strmota, 2017.). Kao negativni prediktori skrbi za starije ističu se slabiji zdravstveni status skrbnika i broj djece u kućanstvu. Također, veću vjerojatnost skrbi za starije imaju osobe koje trenutno nisu na tržištu rada i koje su obrazovanije (Strmota, 2017.). Hosseinpoor, Bergen i Chatterji (2013.) analizom poda-

\section{8 članci}


taka Svjetskog zdravstvenog istraživanja u 48 zemalja među koje se ubraja i Hrvatska, pronalaze kako je vjerojatnost pružanja povremene brige roditelju viša u obiteljima višeg socioekonomskog i obrazovnog statusa, kod osoba koje žive s partnerom, u gradskim sredinama i koje su zaposlene. Kod osoba srednje dobi, s obzirom na sve kasniji odlazak mladih iz roditeljskog doma, pronalazi se nerijetko fenomen takozvane »sendvič generacije«, koja se istovremeno suočava sa zadaćama brige za oslabjele starije i potpore mlađoj odrasloj djeci (Podgorelec i Klempić, 2007.). Stoga Svjetska zdravstvena organizacija (2015.) naglašava važnost razvoja dostupnosti formalne skrbi i prilagođenih radnih uvjeta kako bi se smanjila opterećenost potencijalnih skrbnika. Druge karakteristike obiteljske strukture također se pokazuju odrednicama spremnosti i stupnja uključenosti osobe u brigu za starijeg roditelja: red rođenja, broj maloljetnih u obitelji i udaljenost mjesta stanovanja roditelja i djece (Pillemer i Suitor, 2013.; Čudina-Obradović i Obradović, 2004.). Za planiranje i usmjeravanje intervencija bilo bi korisno razumjeti odnos ovih sociodemografskih obilježja i očekivanja o brizi u ranijim razvojnim fazama obitelji, kada potreba za filijalnom skrbi još nije nastupila.

Cicirelli (1993.) je stanje zabrinutosti za posljedice opadanja zdravlja roditelja i predviđanja odrasle djece o budućoj skrbi za starijeg roditelja imenovao filijalna anksioznost. Pri tome izvori anksioznosti mogu proizlaziti iz sumnje u vlastite sposobnosti adekvatnog odgovora na zahtjeve skrbničke uloge ili pak zabrinutosti za opadanje roditeljevog blagostanja i predviđanje gubitka. Roditeljevo zdravlje je primarni predmet zabrinutosti odrasle djece za vlastite roditelje (Hay, Fingerman i Lefkowitz, 2008.), jednako važno odrasloj djeci srednje kao i mlađe dobi što upućuje na rani razvoj filijalne anksioznosti, koji prethodi pojavi ozbiljnijih znakova zdravstvenih problema roditelja. Silverstein i sur. (2002.) navode kako je podrška pružena bolesnom roditelju s kojim odraslo dijete nema zadovoljavajući afektivni odnos i dalje viša od one koju djeca pružaju zdravim roditeljima s kojima imaju kvalitetan i topao odnos. Osjećaji filijalne anksioznosti te s njima povezana očekivanja o vlastitoj filijalnoj brizi pojavljuju se stoga i prije preuzimanja uloge obiteljskog njegovatelja.

Razgovor o budućoj skrbi nerijetko se u obiteljima odgađa, a primatelji i pružatelji skrbi pronalaze se nespremni u ulozi koja mijenja njihov dugogodišnji odnos (Fowler, Fisher i Pitts, 2014.). Noviji trendovi u skrbi za starije orijentirani su na prevenciju slabljenja kognitivnih i fizičkih sposobnosti kroz promociju aktivnog starenja i razvoj društvene mreže potpore umjesto dosadašnjeg ograničavanja na rješavanje zdravstvenih ili financijskih teškoća (Puljiz, 2016.). Ovaj pristup promovira aktivno sudjelovanje starijih u odlučivanju i ranije preuzimanje odgovornosti za planiranje skrbi. U prilog održavanju autonomije starijih govore i nalazi kako zadovoljstvo životom raste s porastom percepcije vlastite kompetencije i recipročnosti odnosa $s$ obiteljskim skrbnikom (Shahyad i sur., 2011.; Suitor, Gilligan i Pillemer, 2014.). S druge strane, Shen i Yeatts (2013.) pronalaze kako je percipirana dostupnost buduće obi- 
teljske podrške snažan prediktor zadovoljstva životom starijih osoba. lako primanje solidarnosti članova obitelji uglavnom ima pozitivne ishode na dugovječnost i samopoštovanje, ono može djelovati i kao prijetnja autonomiji i dobrobiti pojedinca (Silverstein i sur., 2002.). Suitor, Gilligan i Pillemer (2014.) pronašli su kako majke u starijoj dobi doista imaju specifične i trajne preferencije vezane uz odabir djeteta od kojega u starosti žele primati značajniju brigu, temeljene na percipiranoj empatičnosti i emocionalnoj responzivnosti djeteta. Kod majki čije preferencije skrbništva nisu poštovane, pronađene su niže razine psihološke dobrobiti te viša depresivnost nego kod onih o kojima su se skrbila ranije odabrana odrasla djeca. Stoga Fowler, Fisher i Pitts (2014.) predlažu ranije obiteljsko pregovaranje specifičnih očekivanja o vrsti obiteljske podrške koju pojedini članovi mogu pružiti, a stariji očekuju primiti.

Razumijevanje uloge odrasle djece u zbrinjavanju roditelja u starijoj dobi uključuje otkrivanje prevladavajućih društvenih normi i osobnih stavova o filijalnoj odgovornosti (del Corso i Lanz, 2013.). Bengtson i sur. (2002.) kao okvir istraživanja obiteljske podrške predlažu model međugeneracijske solidarnosti kojim opisuju šest dimenzija uzajamnog brižnog ponašanja članova obitelji. Svaka dimenzija može se manifestirati u aktivnom ili pasivnom obliku: dimenzija afektivne solidarnosti izražava se kroz intimnost ili distancu u odnosu, dimenzija solidarnosti konsenzusa opisuje slaganje ili sukob stavova, vrijednosti i životnih stilova dviju generacija, a stupanj solidarnosti druženja manifestira se uključivanjem člana obitelji u zajedničke aktivnosti ili, suprotno, izolacijom. Dimenzija funkcionalne solidarnosti razlikuje stanja ekonomske ili instrumentalne zavisnosti među članovima obitelji od stanja autonomije. Strukturalna solidarnost odnosi se na objektivne mogućnosti ili prepreke suživota, a najčešće se operacionalizira prostornom udaljenošću mjesta stanovanja. Konačno, normativna solidarnost opisuje stupanj osjećaja dužnosti prema članovima obitelji koji je izražen u dihotomiji individualnih i obiteljskih vrednota. Primjena teorije međugeneracijske solidarnosti na istraživanja očekivanja o brizi posebno je pogodna jer ne odgovara samo na pitanje hoće li odrasla djeca iskazati svoju filijalnu odgovornost, već i na koje načine i u kojoj mjeri. Ove dimenzije mogu biti izražene u različitom stupnju, a dominantnost jedne, poput funkcionalne solidarnosti, može biti odraz kompenziranja nedostataka neke druge dimenzije, poput one afektivne. Ova teorija u empirijskim je istraživanjima ukazala na vrijednost višedimenzionalne konceptualizacije međugeneracijske solidarnosti i mogućnosti generalizacije postojećih spoznaja o izvan-obiteljskoj društvenoj podršci (Hlebec, Šircelj i Mrzel, 2010.).

Dok su istraživanja trenutno pružene neformalne skrbi za starije i skrbničkog opterećenja kod njegovatelja dovela do određenih spoznaja o demografskim karakteristikama pružatelja i primatelja skrbi, rijetka su ispitivanja očekivanja buduće filijalne solidarnosti koja bi doprinijela razumijevanju razlika u poimanju filijalne solidarnosti iz perspektive roditelja i perspektive odrasle djece. Pojavljuje se također i potreba za razvojem mjernih instrumenata kojima bi se provjerilo očekivanja

\section{0 članci}


buduće filijalne brige, kako kod odrasle djece kao mogućih pružatelja, tako i kod roditelja kao mogućih primatelja neformalne obiteljske skrbi.

\section{CILJEVI}

Koristeći teorijski okvir višedimenzionalne međugeneracijske solidarnosti, opći cilj ovog istraživanja bio je ispitati očekivanja o filijalnoj brizi iz perspektive odrasle djece i roditelja starijih od 54 godine. Ovo je, prema spoznajama autora, jedno od rijetkih istraživanja neformalne skrbi za starije osobe u fazi očekivanja, odnosno prethodno pojavi potrebe za aktiviranjem ponašanja filijalne brige. Također, posebnost ovog istraživanja jest što uzima u obzir dvije različite perspektive: onu roditelja kao mogućih primatelja filijalne brige i onu odrasle djece kao mogućih pružatelja skrbi roditelju. S time u vezi, specifični ciljevi istraživanja bili su:

1. Konstruirati ljestvicu samoprocjene očekivanja filijalne brige za potencijalne pružatelja i primatelje skrbi i provjeriti metrijska obilježja - faktorsku strukturu i pouzdanost.

2. Usporediti očekivanja o filijalnoj brizi odrasle djece i roditelja starije dobi temeljem konstruirane »Ljestvice očekivanja o filijalnoj brizi«.

3. Provjeriti razlikuju li se očekivanja o filijalnoj brizi za starijeg roditelja kod odrasle djece i roditelja ovisno o sociodemografskim obilježjima sudionika (spolu djece, broju njihove maloljetne djece i udaljenosti mjesta stanovanja roditelja i djece).

\section{METODA}

\section{Sudionici}

Istraživanje je provedeno na dva nezavisna uzorka ispitanika: jedan uzorak čine starije osobe u ulozi roditelja kao mogućeg primatelja filijalne skrbi, dok drugi uzorak čine osobe u ulozi odraslog djeteta kao potencijalnog pružatelja skrbi.

Sudionici u ulozi roditelja ( $N=152$ ) bili su prosječne dobi od 69,88 godina (SD $=6,696)$, od kojih je najmlađa osoba imala 54 , a najstarija 82 godine, te su većim dijelom bile žene $(73,5 \%)$. Sudionici u ulozi majki i očeva bili su ujednačeni po dobi $(t=-1,02, p>0,05)$, samoprocjeni zdravstvenog $(t=-0,11, p>0,05)$ ili imovinskog statusa ( $t=0,42, p>0,05)$, podjednako često (20\%) su izjavljivali da stanuju sa svojom odraslom djecom u istom kućanstvu.

Drugi nezavisni uzorak čine sudionici u ulozi odrasle djece ( $\mathrm{N}=234), 65 \%$ žena, prosječne dobi 41,71 godina ( $S D=8,352)$ u rasponu od 24 do 60 godina. Među sudionicima u ovoj skupini njih $81,6 \%$ i sami su bili roditelji, a $79,5 \%$ njih je bilo u radnom odnosu. 


\section{Instrumentarij}

\section{Sociodemografski podaci}

Prikupljeni su sljedeći sociodemografski podaci: dob i spol, bračni status i procjena zdravstvenog stanja ispitanika i osobe za koju ispitanik odgovara u upitniku (roditelja ili djeteta), ima li referentno odraslo dijete braće ili sestara kao alternativnih izvora filijalne brige, imovinski status ispitanika te udaljenost mjesta stanovanja u odnosu na člana obitelji. Sudionici u ulozi odraslog djeteta upitani su i o broju i dobi njihove djece.

Ispitana sociodemografska obilježja dvaju uzoraka prikazana su u Tablici 1. Osim o vlastitim, sudionici su izvijestili i o sociodemografskim obilježjima referentnog člana obitelji, roditelja za kojega ili djeteta od kojega očekuju filijalnu brigu.

Tablica 1. Demografska obilježja nezavisnih uzoraka odrasle djece $(\mathrm{N}=234)$ i roditelja $(\mathrm{N}=152)$

\begin{tabular}{|c|c|c|c|c|c|c|c|c|c|}
\hline & & \multicolumn{4}{|c|}{ Roditelji } & \multicolumn{4}{|c|}{ Djeca } \\
\hline & & \multicolumn{2}{|c|}{ Samoprocjena } & \multicolumn{2}{|c|}{$\begin{array}{c}\text { Procjena za } \\
\text { vlastitu djecu }\end{array}$} & \multicolumn{2}{|c|}{ Samoprocjena } & \multicolumn{2}{|c|}{$\begin{array}{c}\text { Procjena } \\
\text { za vlastite } \\
\text { roditelje }\end{array}$} \\
\hline & & $\mathbf{N}$ & $\%$ & $\mathbf{N}$ & $\%$ & $\mathbf{N}$ & $\%$ & $\mathbf{N}$ & $\%$ \\
\hline \multirow{4}{*}{ Bračni status } & Samac ili rastavljen/a & 23 & 15,3 & 23 & 15,2 & 38 & 16,3 & 21 & 9,0 \\
\hline & U vezi & 4 & 2,6 & 11 & 7,3 & 22 & 9,4 & 6 & 2,6 \\
\hline & Vjenčan/a & 90 & 59,6 & 105 & 69,5 & 171 & 73,4 & 148 & 63,8 \\
\hline & Udovac/ica & 34 & 22,5 & 12 & 7,9 & 2 & 0,9 & 58 & 24,6 \\
\hline \multirow{3}{*}{ Imovinski status } & $\begin{array}{l}\text { Iznad prosjeka } \\
\text { države }\end{array}$ & 38 & 25,3 & & & 75 & 32,8 & & \\
\hline & Prosječan & 76 & 50,7 & & & 116 & 50,6 & & \\
\hline & $\begin{array}{l}\text { Ispod prosjeka } \\
\text { države }\end{array}$ & 36 & 24,0 & & & 38 & 16,6 & & \\
\hline \multirow{4}{*}{ Procjena zdravlja } & Jako narušeno & 12 & 7,9 & 2 & 1,4 & 2 & 0,9 & 15 & 6,4 \\
\hline & Izraženi problemi & 40 & 26,5 & 10 & 6,7 & 12 & 5,1 & 62 & 26,5 \\
\hline & Povremeni problemi & 78 & 51,7 & 67 & 45,3 & 107 & 45,5 & 129 & 55,1 \\
\hline & Potpuno zdrav & 21 & 13,9 & 69 & 46,6 & 114 & 48,5 & 28 & 12,0 \\
\hline \multirow{3}{*}{$\begin{array}{l}\text { Broj maloljetne } \\
\text { djece u } \\
\text { kućanstvu } \\
\text { odraslog djeteta }\end{array}$} & 0 & & & & & 110 & 47,0 & & \\
\hline & 1 & & & & & 79 & 33,8 & & \\
\hline & 2 i više & & & & & 45 & 19,2 & & \\
\hline \multirow{3}{*}{$\begin{array}{l}\text { Udaljenost } \\
\text { stanovanja }\end{array}$} & Isto kućanstvo & 31 & 20,4 & & & 44 & 19,0 & & \\
\hline & Unutar 1h vožnje & 70 & 46,1 & & & 158 & 67,0 & & \\
\hline & Veća od 1h vožnje & 51 & 33,5 & & & 33 & 14,0 & & \\
\hline
\end{tabular}

\section{2 članci}




\section{Očekivanja o filijalnoj brizi}

Na temelju dimenzija teorije međugeneracijske solidarnosti (Silverstein, Gans i Yung, 2006.) za potrebe ovog istraživanja konstruirana je upitnička mjera »Ljestvica očekivanja o filijalnoj brizik. Ljestvica se sastoji se od 17 opisa očekivanih ponašanja filijalne brige za koje sudionici procjenjuju u kojoj mjeri oni osobno očekuju takva ponašanja u vlastitom odnosu s roditeljem ili odraslim djetetom. Procjene su na skali Likertovog tipa, od 1 (uopće se ne odnosi na mene) do 5 (u potpunosti se odnosi na mene).

Od 17 opisa ponašanja filijalne brige njih 8 je preuzeto iz istraživanja očekivanja o brizi prema starijem roditelju Hamona i Bliesznera (1990.) te se odnose na nekoliko primjera filijalne solidarnosti: suživot, prilagodbu poslovnih i obiteljskih obaveza, žrtvovanje osobnih sloboda, novčanu, emocionalnu i potporu savjetom. I preostale čestice oblikovane su u skladu s dimenzijama teorije međugeneracijske solidarnosti te uključuju primjere ponašanja funkcionalne nenovčane solidarnosti (obavljanje kućanskih poslova, osiguranje prijevoza...), afektivne i solidarnosti druženja.

Ljestvica je pripremljena u dvije verzije: prva je ponuđena uzorku odrasle djece $\mathrm{i}$ ispituje očekivanja o budućem ponašanju prema roditelju i uključenosti u brigu o njemu, a druga je ponuđena uzorku starijih osoba u ulozi roditelja kao budućih primatelja filijalne brige te ispituje očekivanja koja ima prema jednom od svoje odrasle djece koje sudionik odabire na početku upitnika. Teorijski raspon odgovora na »Ljestvici očekivanja o filijalnoj brizi« je od 17 do 85 gdje viši rezultat znači veće očekivanje o filijalnoj brizi.

Uz ponašanja o očekivanoj filijalnoj brizi dodatnim pitanjem višestrukog izbora provjerena su i očekivanja smještaja roditelja u slučaju njegove nemoći. Ponuđene su sljedeće opcije: »(1) potražiti smještaj u domu«, »(2) angažirati stručnjaka za njegu u kući/stanu roditelja«, »(3) djetetovo pružanje njege u kući/stanu roditelja« ili »(4) vlastitom domu«, »(5) ništa od navedenog«, »(6) nešto drugo« ili opcija »(7) nisam još razmišljao/ la o tome«. Omogućen je izbor više odgovora temeljem vlastitih očekivanja o budućem obliku stambenog smještaja i njege starijeg roditelja.

Konačno, radi kontrole uključeno je i pitanje prisilnog izbora: »Jeste li u posljednjih mjesec dana primili neki oblik praktične pomoći od osoba u vašoj okolini?«s mogućnošću odgovora »da« ili »ne«.

\section{Postupak istraživanja}

U istraživanju je korišten prigodan uzorak ispitanika. Sudionici u ulozi roditelja odazvali su se na javni poziv preko klubova umirovljenika Matice umirovljenika grada Rijeke gdje su uz pomoć voditelja istraživanja ispunili upitnike. Sudionike u ulozi odrasle djece kontaktirali su studenti psihologije na javnim prostorima, u susjedstvu 
ili na radnom mjestu. Ispunjavanje upitnika provedeno je individualno papirnatim putem. Sudionicima je objašnjena svrha istraživanja i osigurana je anonimnost. Sudionici u ulozi roditelja procjenjivali su vlastita očekivanja o filijalnoj skrbi od jednog od svoje punoljetne djece pri čemu im je omogućeno, s ciljem osiguranja dobrobiti sudionika, da sami odaberu za koje će od svoje odrasle djece ispunjavati upitnike. Većina ispitanih u ulozi roditelja procijenila je svoja očekivanja u odnosu s odraslom kćeri $(61,8 \%)$. Sudionici koji su odgovarali iz uloge odraslog djeteta procjenjivali su vlastita očekivanja o brizi za jednog od svojih živućih roditelja. U konačnici je $65 \%$ ispitanika usmjerilo svoje odgovore na majku, dok je $35 \%$ navelo svoja očekivanja o brizi za oca. Prosječno trajanje ispunjavanja bilo je 20 minuta.

\section{REZULTATI}

\section{Konstrukcija ljestvice samoprocjene očekivanja filijalne brige i provjera metrijskih karakteristika}

Provedene su dvije eksploratorne faktorske analize glavnih osi (Principal axis factoring, PAF) kojima je provjerena faktorska struktura ljestvice odvojeno na uzorku odrasle djece i roditelja. Na uzorku odrasle djece pronađena je jednofaktorska struktura kojom je objašnjeno $53,38 \%$ varijance. Saturacije pojedinih čestica na faktoru iznosile su između 0,87 i 0,61 uz izuzetak čestice koja se odnosi na zajednički suživot $\mathrm{i}$ čija saturacija iznosi 0,45 . Mjera unutarnje konzistencije na uzorku odrasle djece iznosi $a=0,95$.

Na uzorku roditelja istom metodom ekstrakcije, uz kosokutnu rotaciju pronađena je dvofaktorska struktura: prvi faktor objašnjava 30,95\%, a drugi dodatnih $9,49 \%$ od ukupnih $40,44 \%$ varijance. Među faktorima je pronađena korelacija od $r$ $=-0,39$. Veći broj čestica (11 od 17) na oba faktora ima saturacije iznad 0,30, u matrici strukture koja u obzir uzima i korelaciju među faktorima. U prvom izlučenom faktoru grupiraju se ponašanja koja se vezuju uz roditeljsku potrebu za kontaktom i druženjem, te prihvaćanje djeteta kao izvora sigurnosti u trenutcima potrebe, dok drugi faktor grupira manje izražena roditeljska očekivanja, odražavajući tako potrebu za autonomijom i odbijanje filijalne žrtve. Pri procjeni pripadnosti čestice pojedinom faktoru korišteni su podaci iz matrica strukture i obrasca. Pouzdanost unutarnje konzistencije za 11 čestica prvog faktora iznosi $a=0,85$, dok je za 6 čestica drugog faktora $a=0,81$. Zbog djelomičnog preklapanja više čestica u dvofaktorskoj soluciji na uzorku roditelja provedena je nova faktorska analiza s ciljanom solucijom na jednom faktoru. Ekstrahirani faktor objašnjava 30,69\% ukupne varijance ljestvice očekivanja o brizi odraslog djeteta za roditelja starije dobi. Saturacije pojedinih čestica na faktoru iznosile su između 0,37 i 0,81. Mjera unutarnje konzistencije

\section{4 članci}


jednofaktorske strukture na uzorku roditelja iznosi $a=0,87$. Podaci jednofaktorskih rješenja za oba uzorka prikazani su u Tablici 2., dok su podaci o ispitanoj dvofaktorskoj strukturi dostupni u prilogu.

S ciljem ispitivanja povezanosti percepcije očekivanja o filijalnoj brizi na uzorku roditelja i uzorku odrasle djece s demografskim obilježjima korišten je sumarni rezultat svih čestica jer je skala na oba uzorka pokazala zadovoljavajuću unutarnju pouzdanost uz prihvatljive saturacije svih čestica.

Tablica 2. Podaci o saturacijama čestica jednofaktorske strukture za oba uzorka

\begin{tabular}{|c|c|c|c|c|}
\hline & \multicolumn{2}{|c|}{ Odrasla djeca } & \multicolumn{2}{|c|}{ Roditelji } \\
\hline & $\mathbf{F 1}$ & $\mathbf{r}_{\text {it }}$ & F1 & $\mathbf{r}_{\text {it }}$ \\
\hline $\begin{array}{l}\text { Biti emocionalna potpora pružanjem utjehe ili } \\
\text { ohrabrenja }\end{array}$ & 0,870 & 0,84 & 0,368 & 0,32 \\
\hline Posjećivati roditelja & 0,847 & 0,82 & 0,464 & 0,42 \\
\hline Prilagoditi obiteljske obaveze & 0,819 & 0,80 & 0,684 & 0,65 \\
\hline $\begin{array}{l}\text { Pomoći u prihvaćanju promjena koje dolaze s } \\
\text { godinama }\end{array}$ & 0,816 & 0,78 & 0,636 & 0,59 \\
\hline Planirati buduću zdravstvenu njegu & 0,775 & 0,75 & 0,813 & 0,75 \\
\hline U posebnim prilikama biti zajedno & 0,767 & 0,75 & 0,381 & 0,35 \\
\hline $\begin{array}{l}\text { Družiti se uz opuštajuće zajedničke aktivnosti } \\
\text { (vrtlarenje, televizija, šetnja...) }\end{array}$ & 0,763 & 0,75 & 0,501 & 0,47 \\
\hline Obavljati kupovinu & 0,758 & 0,72 & 0,598 & 0,57 \\
\hline Pomoći oko osobne njege (oblačenje, kupanje...) & 0,751 & 0,73 & 0,645 & 0,59 \\
\hline Savjetovati ili informirati oko važnih životnih pitanja & 0,704 & 0,68 & 0,540 & 0,50 \\
\hline Čuti se telefonom & 0,703 & 0,70 & 0,578 & 0,53 \\
\hline $\begin{array}{l}\text { Pružati redovitu pomoć u obavljanju kućanskih } \\
\text { poslova }\end{array}$ & 0,701 & 0,68 & 0,464 & 0,45 \\
\hline Osigurati prijevoz & 0,678 & 0,65 & 0,530 & 0,50 \\
\hline Prilagoditi svoje poslovne obaveze & 0,677 & 0,66 & 0,515 & 0,49 \\
\hline Novčano pomoći & 0,623 & 0,59 & 0,560 & 0,51 \\
\hline $\begin{array}{l}\text { Prihvatiti žrtvovanje osobne slobode radi pomoći } \\
\text { roditelju }\end{array}$ & 0,606 & 0,60 & 0,474 & 0,45 \\
\hline Živjeti zajedno & 0,447 & 0,44 & 0,492 & 0,47 \\
\hline \multirow[t]{2}{*}{ Ukupni rezultat } & 68,57 & $a=0,95$ & 58,06 & $a=0,87$ \\
\hline & 12,558 & & 13,344 & \\
\hline
\end{tabular}




\section{Usporedba očekivanja o filijalnoj brizi između odrasle djece i roditelja starije dobi}

Kako bi se odgovorilo na drugi cilj istraživanja o očekivanjima o filijalnoj brizi kod odrasle djece i roditelja starije dobi, ispitane su razlike u izraženim očekivanjima o filijalnoj brizi između uzoraka odrasle djece i roditelja. Uspoređene su procjene na razini pojedinih očekivanja, tj. čestica i ukupnog rezultata na ljestvici.

U Tablici 3. prikazani su prosječni odgovori na dva odvojena uzorka te se po pojedinim česticama može uočiti kako sudionici u ulozi odrasle djece pružaju relativno ujednačene odgovore i izražavaju visoka očekivanja o vlastitom pružanju brige za roditelja u starijoj dobi. S druge strane, sudionici u ulozi roditelja, iako također izražavaju određena očekivanja od svoje odrasle djece, pokazuju neujednačene preferencije te su, primjerice, procjene očekivanja o primanju određenih ponašanja brige, poput zajedničkog provođenja vremena izraženije u odnosu na druga ponašanja, poput pomoći u kućanskim obavezama. Odgovori na pojedinačnim česticama na uzorku odrasle djece upućuju na visoke vrijednosti samoprocjene očekivanja o budućem pružanju praktične kao i emocionalne potpore roditelju, kao i na visoke procjene na česticama koje ispituju spremnost na žrtvu poput prilagodbe poslovnih ili obiteljskih obaveza. Razlike između dva uzorka u izraženim očekivanim ponašanjima ispitane t-testom statistički su značajne na većini čestica te su vrijednosti prikazane u Tablici 3.

Tablica 3. Usporedba samoprocjene očekivanja pojedinih ponašanja filijalne brige nezavisnih uzoraka odrasle djece $(\mathrm{N}=234)$ i roditelja $(\mathrm{N}=151)$

\begin{tabular}{|c|c|c|c|c|c|c|}
\hline & \multicolumn{2}{|c|}{ Roditelji } & \multicolumn{2}{|c|}{ Djeca } & \multirow{2}{*}{$t$} & \multirow{2}{*}{$\begin{array}{c}\text { Choenov } \\
\text { d }\end{array}$} \\
\hline & $M$ & SD & $M$ & SD & & \\
\hline Savjetovati ili informirati... & 3,62 & 1,351 & 4,41 & 0,936 & $-4,50^{* *}$ & 0.71 \\
\hline Biti emocionalna potpora... & 4,34 & 1,006 & 4,32 & 0,861 & 0,18 & -0.02 \\
\hline U posebnim prilikama biti zajedno... & 4,41 & 0,933 & 4,12 & 1,047 & $2,80^{* *}$ & -0.28 \\
\hline $\begin{array}{l}\text { Pomoći u prihvaćanju promjena koje dolaze } \\
\text { s godinama... }\end{array}$ & 3,98 & 1,203 & 4,30 & 0,857 & $-3,04^{*}$ & 0,32 \\
\hline Čuti se telefonom... & 3,99 & 1,324 & 4,00 & 1,188 & $-0,08$ & 0,01 \\
\hline Planiranje zdravstvene njege... & 3,52 & 1,399 & 4,12 & 1,035 & $-4,83^{* *}$ & 0,51 \\
\hline Družiti se uz opuštajuće aktivnosti... & 3,51 & 1,469 & 3,78 & 1,138 & $-2,04^{*}$ & 0,21 \\
\hline Posjećivati ... & 4,38 & 1,006 & 4,29 & 0,913 & 0,94 & 0,09 \\
\hline Osigurati prijevoz... & 3,59 & 1,430 & 4,34 & 0,913 & $-6,27^{* *}$ & 0,66 \\
\hline Pomoći oko osobne njege... & 3,52 & 1,500 & 3,78 & 1,043 & $-5,64 * *$ & 0,20 \\
\hline
\end{tabular}

\section{6 članci}




\begin{tabular}{lccccccc}
\hline & \multicolumn{2}{c}{ Roditelji } & \multicolumn{2}{c}{ Djeca } & & \multicolumn{2}{c}{ Choenov } \\
\cline { 2 - 5 } & $\mathbf{M}$ & SD & M & SD & & d \\
\hline Novčano pomoći... & 3,27 & 1,514 & 4,20 & 0,982 & $-7,27^{* *}$ & 0,76 \\
Pomoći u kućanskim poslovima... & 2,19 & 1,349 & 3,67 & 1,135 & $-11,60^{* *}$ & 1,21 \\
Živjeti zajedno... & 2,47 & 1,531 & 2,59 & 1,334 & $-0,84$ & 0,08 \\
Obavljati kupovinu... & 3,42 & 1,489 & 4,41 & 0,870 & $-8,22^{* *}$ & 0,86 \\
Prilagoditi obiteljske obaveze... & 2,95 & 1,462 & 4,25 & 0,864 & $-10,94^{* *}$ & 1,15 \\
Prilagoditi poslovne obaveze... & 2,55 & 1,417 & 4,03 & 0,940 & $-12,29^{* *}$ & 1,28 \\
Prihvatiti žrtvovanje osobne slobode... & 2,35 & 1,420 & 3,72 & 1,091 & $-10,64^{* *}$ & 1,11 \\
\hline Ukupan rezultat & 58,06 & 13,344 & 68,57 & 12,558 & $-7,83^{* *}$ & 0,81 \\
\hline
\end{tabular}

${ }^{*} p<0,05 ; * * p<0,01$

Na samoprocjeni očekivanja »u posebnim prilikama biti zajedno« sudionici u ulozi roditelja izrazili su značajno viša očekivanja od sudionika u ulozi odrasle djece. Na preostalim česticama sudionici u ulozi odrasle djece izražavali su viša očekivanja o pružanju brige roditelju u starijoj dobi u odnosu na ona koja su izražavali sudionici roditelji odrasle djece. Roditelji najniža prosječna očekivanja izražavaju prema praktičnoj pomoći u kućnim poslovima ili ponašanjima koja eksplicitno zahtijevaju odricanja od ulaganja u druge ciljeve poput prilagodbe obiteljskih i poslovnih obaveza te žrtvovanje osobne slobode prema čemu su odrasla djeca izražavala veća očekivanja od svog angažmana u filijalnoj skrbi. Nisu pronađene razlike u očekivanju emocionalne potpore odraslog djeteta roditelju, telefonskoj komunikaciji, posjetima i zajedničkom stanovanju.

Odgovori na pitanje koje se odnosi na očekivanja o budućem obliku stambenog smještaja i njege starijeg roditelja i u kojemu je omogućen odabir više ponuđenih mogućnosti, analizirani su primjenom neparametrijske statistike kako bi se usporedila frekvencija izbora svakog od odgovora između uzorka odrasle djece i roditelja. U Tablici 4. prikazane su opažene frekvencije i proporcije sudionika u oba uzorka prema odgovorima o preferenciji osiguranja ili prihvaćanja nekog od oblika smještaja i organizacije njege za roditelja u slučaju nemoći te rezultati $\chi^{2}$ testa uz svaku opciju. 
Tablica 4. Prikaz frekvencija i postotaka sudionika u dva uzorka prema odabiru opcije smještaja i njege roditelja kao prihvatljive

\begin{tabular}{|c|c|c|c|c|c|c|}
\hline & \multicolumn{2}{|c|}{$\begin{array}{l}\text { Roditelji } \\
(N=150)\end{array}$} & \multicolumn{2}{|c|}{$\begin{array}{c}\text { Odrasla } \\
\text { djeca } \\
(\mathrm{N}=233)\end{array}$} & \multirow[t]{2}{*}{$\chi^{2}$} & \multirow[t]{2}{*}{$\varphi$} \\
\hline & $f_{0}$ & $\%$ & $f_{0}$ & $\%$ & & \\
\hline $\begin{array}{l}\text { 1. Smještaj u domu za starije i } \\
\text { nemoćne osobe }\end{array}$ & 50 & 33,33 & 120 & 51,50 & $12,20^{* *}$ & $0,18^{* *}$ \\
\hline $\begin{array}{l}\text { 2. Angažiranje stručnjaka za njegu } \\
\text { u kući/stanu roditelja }\end{array}$ & 42 & 28,00 & 120 & 51,50 & $20,14^{* *}$ & $0,23^{* *}$ \\
\hline $\begin{array}{l}\text { 3. Osobno pružanje njege u kući/ } \\
\text { stanu roditelja }\end{array}$ & 41 & 30,90 & 128 & 54,93 & $28,20^{* *}$ & $0,27^{* *}$ \\
\hline $\begin{array}{l}\text { 4. Osobno pružanje njege u kući/ } \\
\text { stanu odraslog djeteta }\end{array}$ & 11 & 7,33 & 85 & 36,48 & $41,27^{* *}$ & $0,33^{* *}$ \\
\hline 5. Nisam još razmišljao o tome & 47 & 31,33 & 55 & 23,70 & 2,71 & $-0,08$ \\
\hline 6. Ništa od navedenog*** & 3 & 2,10 & 3 & 1,00 & 0,68 & n.p. \\
\hline
\end{tabular}

${ }^{*} p<0,05 ;{ }^{* *} p<0,01 ; f_{o}$ - opažene frekvencije izbora opcije, sudionici su mogli izabrati više od jedne opcije pa kumulativ nije 100; ${ }^{* *}$ zbog male veličine $f_{o}$ korišten je Fisher exact test, n.p. = nije primjenjivo

Odrasla djeca češće biraju po dvije od ponuđenih opcija, dok stariji roditelji najčešće biraju samo jednu alternativu preferencije smještaja, što upućuje i na veću spremnost mlađih sudionika na osiguranje više različitih oblika potpore starijem roditelju u odnosu na spremnost starijih osoba na očekivanje različitih oblika zbrinjavanja. Dok polovica uzorka u ulozi odrasle djece kao moguću opciju smještaja bira smještaj u domu za starije osobe, ista opcija izabrana je od strane jedne trećine mogućih budućih primatelja skrbi, što predstavlja značajnu razliku. Slično, sudionici u uzorku odrasle djece statistički su značajno češće birali opcije angažiranja stručnjaka ili osobnog pružanja skrbi u vlastitom ili kućanstvu člana obitelji. Nisu pronađene razlike među uzorcima u frekvenciji izbora odgovora »nisam razmišljao o tome« te je veći dio sudionika u ulozi odrasle djece i roditelja o ovoj temi već razmišljala. Također, moguće je da je dio sudionika odabrao posljednju opciju i kako bi izbjegli izjašnjavanje o drugim ponuđenim preferencijama. $U$ oba uzorka neznatan dio sudionika nije odabrao ni jedan od ponuđenih oblika smještaja.

\section{8 članci}




\section{Očekivanja o filijalnoj brizi kod odrasle djece s obzirom na sociodemografska obilježja djece i njihovih roditelja}

Na uzorku odrasle djece provjerene su razlike očekivanja o brizi ovisno o razini odabranih, teorijski relevantnih sociodemografskih obilježja uz prethodnu provjeru povezanosti ovih varijabli izračunom Spearmanovih koeficijenata korelacije. Nisu pronađene značajne korelacije između filijalnih očekivanja o brizi za roditelja i procijenjenog imovinskog ili zdravstvenog stanja roditelja, postojanju dostupne braće i sestara odraslog djeteta niti udaljenosti mjesta stanovanja. Korelacije očekivanja o brizi i demografskih varijabli prikazane su u Tablici 5.

Tablica 5. Korelacije procjena očekivanja odrasle djece o brizi za vlastite roditelje u starijoj dobi i demografskih varijabli

\begin{tabular}{lccccccc}
\hline & $\begin{array}{c}\text { Spol } \\
\text { roditelja }\end{array}$ & $\begin{array}{c}\text { Spol } \\
\text { odraslog } \\
\text { djeteta }\end{array}$ & $\begin{array}{c}\text { Imali } \\
\text { sudionik } \\
\text { maloljetne } \\
\text { djece }\end{array}$ & $\begin{array}{c}\text { Imovinsko } \\
\text { stanje } \\
\text { djeteta }\end{array}$ & $\begin{array}{c}\text { Zdravlje } \\
\text { roditelja }\end{array}$ & $\begin{array}{c}\text { Imali } \\
\text { sudionik } \\
\text { braće? }\end{array}$ & $\begin{array}{c}\text { Udaljenost } \\
\text { mjesta } \\
\text { stanovanja }\end{array}$ \\
\hline $\begin{array}{l}\text { Očekivanja } \\
\text { o filijalnoj brizi }\end{array}$ & $-0,15^{*}$ & $-0,22^{* *}$ & $0,23^{* *}$ & 0,03 & 0,03 & 0,09 & $-0,07$ \\
\hline
\end{tabular}

${ }^{*} p<0,05 ;{ }^{* *} p<0,01$; Spol roditelja i odraslog djeteta kodiran je na sljedeći način: $0=$ žene, $1=$ muškarci; Pitanja kojima se provjerava ima li sudionik maloljetne djece i braće kodirana su ovako: $0=$ nema, 1 = ima jedno ili više maloljetne djece/braće

Dvosmjernom analizom varijance ispitana je razlika u izraženim očekivanjima odraslog djeteta o budućem pružanju brige roditelju kod muškaraca i žena ovisno o tome imaju li maloljetnu djecu ili nemaju. Pronađena je statistički značajna razlika u izraženim očekivanjima o brizi ovisno o spolu odraslog djeteta $\left(\mathrm{F}=11,82, \mathrm{p}<0,01, \mu^{2}=0,05\right)$ i roditeljstvu vlastitom maloljetnom djetetu ( $\mathrm{F}=$ $\left.12,94, p<0,01, \mu^{2}=0,05\right)$. Žene $(M=70,26 ; S D=10,934)$ izražavaju značajno viša očekivanja o vlastitoj brizi za roditelja u starijoj dobi u odnosu na muškarce ( $M=$ $64,32 ;$ SD $=14,737)$. Osobe koje su roditelji maloljetne djece izražavaju značajno viša očekivanja o brizi za vlastitog roditelja $(M=71,03 ; S D=10,437)$ u odnosu na sudionike koji nemaju maloljetne djece $(M=65,47 ; S D=13,994)$. Nije pronađen značajan interakcijski efekt spola sudionika i njegovog imanja odnosno nemanja vlastite djece $\left(F=1,22, p>0,05, \mu^{2}=0,01\right)$. 


\section{Očekivanja o filijalnoj brizi kod roditelja s obzirom na sociodemografska obilježja roditelja i njihove djece}

Na uzorku roditelja odrasle djece izračunati su Spearmanovi i Pearsonovi koeficijenti korelacije demografskih obilježja i ukupnih očekivanja o brizi što je prikazano u Tablici 6. Osim demografskih podataka analizirani su i odgovori na kontrolno pitanje jesu li roditelji u posljednjih mjesec dana primili neki oblik praktične pomoći od osoba u svojoj okolini.

Tablica 6. Korelacije nekih demografskih varijabli i procjene očekivanja o primanju filijalne brige dobivene na uzorku roditelja

\begin{tabular}{cccccccc} 
Dob & Spol & Spol & Imovinsko & & Imali & Udaljenost & Prima li \\
sudionika & roditelja & $\begin{array}{c}\text { odraslog } \\
\text { djeteta }\end{array}$ & $\begin{array}{c}\text { stanje } \\
\text { roditelja }\end{array}$ & $\begin{array}{c}\text { Zdradionik } \\
\text { roditelja }\end{array}$ & $\begin{array}{c}\text { još odrasle } \\
\text { mjesta }\end{array}$ & $\begin{array}{c}\text { neki oblik } \\
\text { stanovanja }\end{array}$ & pomoći? \\
\hline
\end{tabular}

Očekivanja

$\begin{array}{llllllll}\text { o filijalnoj } \quad 0,16^{*} & -0,07 & -0,06 & -0,13 & -0,05 & 0,06 & -0,20^{*} & 0,27^{* *}\end{array}$

brizi

${ }^{*} \mathrm{p}<0,05 ;{ }^{* *} \mathrm{p}<0,01 ; 66 \%$ sudionika potvrdilo je kako prima neki oblik pomoći od osoba iz okoline

Većina demografskih varijabli (spol roditelja ili djeteta za koje odgovara, imovinski status, broj odrasle djece) nije značajno korelirana s ukupnim očekivanjima o brizi, uključujući i samoprocjenu zdravstvenog stanja kao mogući pokazatelj potrebe za filijalnom brigom. Značajne korelacije s ukupnim očekivanjima o brizi pronađene su s procjenama prostorne udaljenosti mjesta stanovanja roditelja $i$ djece, dobi roditelja i tvrdnjom o trenutnom primanju funkcionalne solidarnosti. Dvosmjernom analizom varijance testirane su razlike $u$ izraženim očekivanjima o budućem primanju filijalne brige kod roditelja odrasle djece ovisno o udaljenosti mjesta stanovanja na tri razine i kodirane na idući način: »(1) u istom kućanstvu«, »(2) unutar« ili »(3) na udaljenosti većoj od jednog sata vožnje« i primanju funkcionalne solidarnosti okoline kodiranom kao dihotomna varijabla $(\mathrm{da}=1$, ne $=0$ ).

Značajan efekt primanja funkcionalne solidarnosti $\left(F=8,71, p<0,01, \mu^{2}=0,06\right)$ ukazuje na mogućnost većeg izražavanja očekivanja o budućem primanju filijalne brige kod sudionika koji i trenutno primaju određenu pomoć osoba iz okoline ( $M$ $=60,78 ; \mathrm{SD}=12,794)$ u odnosu na one koji su izjavili da nisu u posljednjih mjesec dana primali pomoć $(M=53,17 ; S D=12,932)$. Premda je snaga pronađenog efekata relativno mala, upućuje na ulogu trenutno primljene filijalne solidarnosti u formira-

\section{0 članci}


nju očekivanja o budućnosti. Nisu pronađene značajne razlike ovisno o udaljenosti mjesta stanovanja odraslog djeteta i roditelja $\left(F=2,79, p>0,05, \mu^{2}=0,04\right)$ kao niti interakcijski efekti $\left(F=2,86, p>0,05, \mu^{2}=0,04\right)$.

\section{RASPRAVA}

Prikazani rezultati u skladu su s nalazima ranijih istraživanja, ali ih i nadopunjuju. Ispitujući očekivanja filijalne solidarnosti, Hamon i Blieszner (1990.) pronašli su veću spremnost na pružanje brige kod obiteljskih njegovatelja nego što su bila izražena očekivanja roditelja primatelja skrbi. Slično, u provedenom istraživanju sudionici u ulozi roditelja procjenjivali su niže stupnjeve očekivanja o filijalnoj brizi na nizu primjera ponašanja poput pomoći u kućanskim poslovima ili prihvaćanja prilagodbe djetetovih poslovnih obaveza, te su birali manje različitih opcija osiguranja smještaja. S druge strane, sudionici u ulozi roditelja su uglavnom izrazili povoljan stav prema formalnim oblicima zbrinjavanja: trećina sudionika prihvaća smještaj u dom za starije i nemoćne, a $28 \%$ ih je zainteresirano za korištenje usluga stručnog osoblja u svom domu. Još jedna preferirana opcija jest i primanje povremene njege odraslog djeteta u vlastitom kućanstvu, što podrazumijeva i zadržavanje određene razine autonomije. Istraživanja kulturalnih specifičnosti normi filijalne solidarnosti (Kawakami i Son, 2015.) ističu kako starije osobe teže izražavanju preferencija formalnih oblika skrbi kako ne bi predstavljale teret svojim obiteljima. Wenzel i Poynter (2014.) pronalaze kod starijih osoba verbalno odbacivanje normi filijalne odgovornosti te izraženu potrebu za autonomijom, povezanu i s osobnim iskustvom skrbničkog opterećenja. Priznavanje potreba njege i ovisnosti o vlastitoj djeci zahtjeva redefiniranje vlastitog identiteta kao samostalne odrasle osobe, što predstavlja izazovan razvojni zadatak starije dobi (Mendonca i Fontaine, 2014.). Tako Fowler, Fisher i Pitts (2013.) učestalost izbjegavanja planiranja budućnosti kod osoba starije dobi povezuju sa subjektivnom neugodom suočavanja sa slabljenjem vlastitih sposobnosti. Rezultati ovog istraživanja ukazuju kako skoro trećina sudionika u ulozi roditelja izjavljuje kako još nije razmišljala o obliku svog budućeg smještaja u slučaju potrebe.

Objašnjenje nalaza nižih očekivanja filijalne brige kod sudionika u ulozi roditelja moglo bi se pronaći u osjećaju ambivalencije. Teorija međugeneracijske solidarnosti ističe vrijednost istovremenog postojanja pozitivnih i negativnih emocija prema članu obitelji u procesu prihvaćanja različitosti međugeneracijskih normi (Bengston i Oyama, 2007.). Na to upućuje i pronađena dvofaktorska struktura »Ljestvice očekivanja o brizi za starijeg roditelja« (dostupno kod autora). Prvi faktor čine čestice koje opisuju ponašanja afektivne i solidarnosti druženja te se čini da su sudionici u ulozi roditelja skloniji primanju ovih oblika brige. Drugi je faktor više zasićen česticama koje uključuju žrtvovanje djetetovih osobnih sloboda, prilagodbu obveza, ispunja- 
vanja zadataka održavanja kućanstva ili očekivanje o suživotu. Ova grupa čestica predstavlja zadatke koji zahtijevaju veći napor odraslog djeteta, a time i percepciju mogućeg većeg skrbničkog opterećenja, podrazumijevajući i veću potrebitost roditelja. Primjerice, nemogućnost samostalnog obavljanja kućanskih poslova podrazumijeva određeni stupanj narušenosti kompetencije i samodostatnosti roditelja.

Ispitujući norme filijalne brige van der Pas, van Tilburg i Knipscheer (2005.) kao najvažnije za starije roditelje ističu norme afektivne, solidarnosti druženja i norme vezane uz informiranje. Slični primjeri ponašanja emocionalne potpore, razgovori telefonom ili druženje u posebnim prilikama i u ovom su se istraživanju istaknuli kao izražena očekivanja roditelja odrasle djece. Navedeni autori su kao najmanje izražene norme pronašli primjere praktične i financijske pomoći odrasle djece te ponašanja koja uključuju poslovnu ili privatnu žrtvu. Usporediva ponašanja prilagodbe obiteljskih ili poslovnih obaveza te žrtve osobne slobode u ovom su istraživanju manje očekivana od strane roditelja. Primanje financijske pomoći umjereno je očekivano što ukazuje na izazove u pokušajima generalizacije nalaza stranih istraživanja zbog različitosti kulturalnih i ekonomskih uvjeta života hrvatskih obitelji pored vršnjaka u zapadnim državama Europske unije. Teoretičari međugeneracijske solidarnosti (Silverstein i sur., 2002.) upozoravaju kako su roditeljska očekivanja o brizi vezana uz kontekst potrebe za brigom, te da je jedno ponašanje podrške moguće interpretirati iz roditeljske uloge na više načina - kao oblik instrumentalne potpore ili solidarnosti druženja, kao znaka topline odnosa ili smanjenja vlastite autonomije.

Razlike u izraženosti očekivanja o brizi ovisno o spolu djeteta, prospektivnog pružatelja skrbi koje su pronađene u ovom istraživanju, na tragu su demografskih podataka o većoj uključenosti žena, kćeri ili snaha, u brigu o starijim osobama (WHO, 2015.; Hosseinpoor, Bergen i Chatterji, 2013.). Longitudinalna istraživanja nalaze kako se obiteljske vrijednosti koje se odnose na brigu o starijima uspješnije prenose na kćeri nego na sinove što je u skladu i s kulturalnim razumijevanjem koje ulogu žene često vezuje uz ponašanja njegovanja (Silverstein, Gans i Yang, 2009.). Razlike u očekivanjima od kćeri i od sinova pronađene su u ovom istraživanju samo na uzorku odrasle djece, ne i roditelja. Objašnjenje je moguće tražiti u samoj metodi istraživanja u kojoj su se roditelji izjašnjavali o svojim očekivanjima u odnosu na samo jedno dijete, a ne u usporedbi s drugom djecom. Također, usprkos nastojanjima ujednačavanja uzoraka o spolu, u ovom istraživanju je u oba nezavisna uzorka broj sudionica veći od broja sudionika, što otežava mogućnost generalizacije dobivenih rezultata. Konačno, nije poznat spol braće ili sestara odrasle djece za koju su odgovarali sudionici u uzorku roditelja. Grigoryeva (2017.) pokazuje kako sinovi pružaju roditeljima značajno manje njege ukoliko imaju sestre. Stoga je za ispitivanje razlike u očekivanju o brizi kćeri ili sina na uzorku odraslih roditelja potrebno

\section{2 članci}


prikupiti i dodatne podatke o obiteljskoj strukturi te ujednačiti uzorke i po ovim karakteristikama, što na analiziranom prigodnom uzorku nije bilo moguće učiniti.

Ovim istraživanjem utvrđena je statistički značajna korelacija roditeljstva maloljetnoj djeci i očekivanja o filijalnoj brizi kod odrasle djece. Prisutnost djece u kućanstvu može predstavljati izvor socijalne podrške pružatelju brige (Gopalan, Miller i Brannon, 2013.) ili biti izvor razumijevanja roditeljske uloge i motivacije za reciprocitet. Ipak, nije zanemarivo niti da maloljetna djeca u kućanstvu mogu biti i izvor dnevnog opterećenja, pa tako Carpenter (2001.) pronalazi da je ovo obilježje ujedno prediktor veće uključenosti u skrb za roditelja kao i većeg skrbničkog tereta odraslog djeteta.

Većina demografskih obilježja odrasle djece poput udaljenosti mjesta stanovanja, postojanja braće ili imovinskog statusa, koja su često navedena kao prediktori skrbničke uloge (Hosseinpoor, Bergen i Chatterji, 2013.; Pillemer i Suitor, 2013.) nisu bila značajno korelirana s očekivanjima o brizi odrasle djece. Moguće je da su ova obilježja povezana s pružanjem brige i skrbi u situaciji roditeljske nemoći, ali ne i s izražavanjem očekivanja pružanja buduće brige. Razumijevanje razlike između očekivane i pružene brige za starijeg roditelja zahtijevalo bi primjenu longitudinalnog nacrta istraživanja. Konačno, ispitivanje psiholoških odrednica omogućilo bi bolje razumijevanje mehanizama formiranja očekivanja o filijalnoj brizi u kontekstu razvojnih i sistemskih teorija, te odgovorilo na pitanje kako se afektivna kvaliteta odnosa roditelja i djece odražava na stvaranje očekivanja buduće filijalne skrbi.

Korištenje tek jednog pitanja kao mjere zdravstvenog stanja ograničava mogućnosti zahvaćanja varijabiliteta zdravstvenog stanja starijih osoba. Procjene vlastitog zdravlja kod osoba starije dobi često su precijenjene s obzirom na prisutnost realnih tegoba (Petrak, Despot-Lučanin i Lučanin, 2006.). Uključivanje mjera funkcionalnih sposobnosti omogućilo bi objektivniju kontrolu valjanosti ovih samoprocjena.

\section{PRAKTIČNE IMPLIKACIJE}

Možemo ustvrditi da se znanstveni doprinos ovog rada ogleda u doprinosu konstrukcije mjere i tematiziranja koncepta očekivane filijalne brige. Konstruiranu ljestvicu moguće je primjenjivati u istraživanjima psihosocijalnih odrednica neformalne skrbi za starije osobe o kojima na domaćem uzorku postoji manji broj istraživanja (Čudina-Obradović i Obradović, 2004.). Također, u longitudinalnim istraživanjima, ljestvicom bi bilo moguće ispitati i prediktivne efekte ranijih očekivanja na kasnije pružanje brige i njege roditelju u starijoj dobi.

Društvena korisnost istraživanja očekivanja o brizi za starijeg roditelja i njihovih korelata prepoznaje se u mogućnosti preventivnog prepoznavanja kako rizičnih skupina, tako i postojećih izvora društvene solidarnosti i mogućnosti javne po- 
drške skrbnicima, a posebno onima slabijeg socioekonomskog statusa i socijalno izoliranima (Žganec, Rusac i Laklija, 2007.; Bađun, 2015.). Pravovremeno aktiviranje sustava socijalne i zdravstvene skrbi u slučajevima zanemarivanja ili zlostavljanja starijih osoba zahtijeva, osim snažnije međusektorske suradnje, i osjetljivu javnost i civilno društvo. Ovo je posebno važno u kontekstu teže prepoznatljivih oblika zlostavljanja poput financijskog nasilja za koje je utvrđeno kako su počinitelji u mnogim slučajevima osobe bliske starijoj žrtvi, članovi obitelji i odrasla djeca (Vuić i Rusac, 2007.). U ovim i drugim slučajevima zlostavljanja ili zanemarivanja je kod starijih roditelja čest osjećaj srama što može spriječiti i povjeravanje stručnim osobama. Društveno prepoznavanje i vrednovanje filijalne odgovornosti korak je k smanjenju stigme prema žrtvama obiteljskog nasilja starije dobi.

Radi očuvanja resursa neformalne skrbi za starije $u$ vremenima pred nama sve su potrebnije edukacije i podrška obitelji u zbrinjavanju starijih članova. Problematizirajući iscrpljujući položaj neformalnih skrbnika osoba s demencijom, čiji radni odnosi nisu zaštićeni posebnim pravnim mehanizmima, Rusac (2016.) naglašava važnost primjene dostupnih mjera socijalne zaštite u podržavanju onih koje skrbe za svoje starije roditelje. Ovo istraživanje specifično je po tome što ispituje prospektivne, odnosno moguće buduće primatelje i pružatelje skrbi, omogućujući nam razlikovanje očekivanja solidarnosti koju starijima primarno može pružiti obitelj pred onima za koje postoji preferencija aktiviranja drugih izvora skrbi. Nalazi o nižim očekivanjima starijih osoba predstavljaju argument u suzbijanju predrasudama o starijim osobama kao nemoćnima i zahtjevnima te ukazuju na važnost poštovanja njihove potrebe duljeg očuvanja funkcionalne samodostatnosti (WHO, 2015.). Uključivanje starijih u planiranje svoje buduće skrbi i odgovora na specifične potrebe omogućuje i razvoj novih oblika usluga u području skrbi za starije osobe, koje će biti po mjeri korisnika, prihvatljive primatelju kao i članovima njegove obitelji, a društvu u cjelini korisne i kao ekonomski održiviji pristup problemu demografskog starenja (Dajaki Orešković, 2018.).

Razlikovanje očekivanja pojedinih oblika filijalne brige ili preferencija različitih oblika smještaja ukazuje na mogućnosti kreiranja preventivnih programa podrške prilagođenih individualnim potrebama starijih, kao i obiteljskih njegovatelja koji anticipiraju vlastiti angažman u brizi za starije roditelje uz vrjednovanje socijalnog kontakta i emotivne potpore starijima. Značajan dio sudionika u oba uzorka izjavljuje kako još nije razmišljalo o oblicima zbrinjavanja starijeg roditelja, što govori u prilog potrebi poticanja pravovremene obiteljske komunikacije i usklađivanja, primjerice kroz medijske kampanje. Metode personaliziranog planiranja u brizi za starije osobe (Mali, 2019.) uvažavaju perspektivu članova obitelji, a posebno starije osobe kao korisnika, te potiču njihovu aktivnu ulogu u izražavanju vlastitih vrijednosti, stavova i preferencija pri postavljanju osobnih ciljeva i definiranju potreba njege. Pri tome je uz multiperspektivnost naglašena i važnost osiguranja vremena dovoljnog za

\section{4 članci}


izradu planova, pri čemu je poznavanje očekivanja osobe iz faze prospektivnog primatelja odnosno pružatelja brige vrijedan izvor informacija.

\section{ZAKLJUČCI}

Prikazanim istraživanjem opisana je konstruirana »Ljestvica očekivanja o filijalnoj brizi«, zadovoljavajuće unutarnje konzistencije čije je rezultate opravdano prikazivati sumarnim rezultatom jednodimenzionalne strukture za obje pripremljene forme upitnika namijenjenog odrasloj djeci kao mogućim pružateljima brige ili roditeljima kao mogućim primateljima.

Dobiveni rezultati upućuju na postojanje razlika u općoj razini izraženih očekivanja kao i u procjenama očekivanja specifičnih ponašanja filijalne pri čemu odrasla djeca izražavaju viša očekivanja vlastite filijalne brige za roditelja: najveće snage efekata pronađene su u ponašanjima koja zahtijevaju prilagodbu drugih obaveza, financijsku, savjetodavnu ili pomoć u kućanskim poslovima. S druge strane, kod ispitanika u ulozi roditelja i djece pronalazi se slaganje u pitanjima održavanja kontakta kroz posjete i telefonske razgovore, očekivanja emocionalne potpore te izostanka očekivanja suživota. Odrasla djeca pri izboru očekivanog smještaja starijeg roditelja biraju veći broj alternativnih oblika skrbi. Dio ispitanika u oba uzorka izjavljuje kako još nije promišljao o preferiranom obliku smještaja.

Pronađena je povezanost nekih sociodemografskih obilježja i postojećih očekivanja filijalne brige. Na uzorku odrasle djece pronađeno je kako značajno viša očekivanja o vlastitom pružanju brige za roditelja izražavaju odrasle kćeri u odnosu na muškarce koji su ispunili upitnik, dok osobe koje nisu roditelji maloljetne djece izražavaju viša očekivanja o vlastitoj filijalnoj brizi u odnosu na one koji imaju mlađu djecu. Kod starijih roditelja koji i trenutno primaju određenu pomoć osoba iz okoline potvrđena su izraženija očekivanja o primanju filijalne brige u budućnosti.

Ograničenja ovog istraživanja vezana su uz obilježja prigodnog uzorka, iako njegova veličina odgovara prethodnim ispitivanjima filijalne solidarnosti (Merz i Consedine, 2009.; Karantzas i sur., 2010.). Ispitivanje očekivanja o filijalnoj brizi kreiranom ljestvicom na širim i reprezentativnim uzorcima starijih osoba omogućilo bi dodatne provjere njene faktorske konceptualizacije na uzorku roditelja. Primjena dobno-spolne stratifikacije uzorka i kontrole uvjeta stanovanja u urbanoj ili ruralnoj sredini omogućila bi pouzdaniju generalizaciju rezultata. Socijalno poželjno odgovaranja kao sistematično precjenjivanje stupnja očekivanja odrasle djece o vlastitoj filijalnoj odgovornosti prijetnja je eksternalnoj valjanosti rezultata istraživanja. Buduća istraživanja mogla bi primjenom zavisnih parova ispitanika roditelja i odrasle djece provjeriti i sukladnost očekivanja o filijalnoj brizi unutar dijada, te omogućiti pouzdanije zaključivanje o razlikama očekivanja iz dviju obiteljskih uloga. 


\section{LITERATURA}

1. Bađun, M. (2015). Neformalna dugotrajna skrb za starije i nemoćne osobe. Newsletter - povremeno glasilo Instituta za javne financije, 100, 1-9. https://doi. org:10.3326/nlh.2015.100

2. Bengtson, V. L., Giarrusso, R., Mabry, J. B. \& Silverstein, M. (2002). Solidarity, conflict, and ambivalence: Complementary or competing perspectives on intergenerational relationships? Journal of Marriage and Family, 64 (3), 568-576. https://doi.org/10.1111/j.1741-3737.2002.00568.x

3. Bengtson, L. V. \& Oyama, S. P. (2007). Intergenerational solidarity: Strengthening economic and social ties. New York: United Nations Headquarters.

4. Carpenter, B. D. (2001). Attachment bonds between adult daughters and their older mothers: Associations with contemporary caregiving. Journal of Gerontology: Psychological Sciences, 56b, 257-266. http://dx.doi.org/10.1093/geronb/56.5.P257

5. Cicirelli, V. G. (1993). Attachment and obligation as daughter's motives for caregiving behaviour and subsequent effects on subjective burden. Psychology and Aging, 8, 144-155.

6. Čudina-Obradović, M. \& Obradović, J. (2004). Psihosocijalne pretpostavke skrbi za stare ljude. Revija za socijalnu politiku, 11 (2), 177-192. https://doi.org/10.3935/ rsp.v11i2.51

7. del Corso, A. R. \& Lanz, M. (2013). Felt obligation and the family life cycle: A study on intergenerational relationships. International Journal of Psychology, 48, 1196-1200. https://doi.org/10.1080/00207594.2012.725131

8. Dajak, L. \& Orešković, S. (2018). Nedostatno korištenje ekonomskih potencijala demografskog starenja u Hrvatskoj, Revija za socijalnu politiku, 25 (1), 99-105. https://doi:10.3935/rsp.v25i1.1528

9. Dobrotić, I. (2016). Razvoj i poteškoće sustava skrbi za starije osobe u Republici Hrvatskoj. Društvena istraživanja, 25 (1), 21-42. https://doi.org/10.5559/di.25.1.02

10. European Commission (2015). The 2015 ageing report - Economic and budgetary projections for the 28 EU Member States (2013-2060). Luxembourg: Publications Office of the European Union. https://doi.org/10.2765/877631

11. Fowler, C., Fisher, L. C. \& Pitts, M. J. (2014). Older adults' evaluations of middle aged children's attempts to initiate discussion of care needs. Health Communication, 29 (7), 717-727. https://doi.org/10.1080/10410236.2013.786278

12. Gopalan, N., Miller, M. M. \& Brannon, L. A. (2013). Motivating adult children to provide support to a family caregiver. Stress Health, 29, 345-348. https://doi. org/10.1002/smi.2480

13. Grigoryeva, A. (2017). Own gender, sibling's gender, parent's gender: The division of elderly parent care among adult children. American Sociological Review. 82 (1), 116-146. https://doi.org/10.1177/0003122416686521

\section{6 članci}


14. Hamon, R. R. \& Blieszner, R. (1990). Filial responsibility expectations among adult child-older parent pairs. Journal of Gerontology, 45, 110-112. https://doi. org/10.1093/geronj/45.3.P110

15. Hay, E. L., Fingerman, K. L. \& Lefkowitz, E. S. (2008). The worries adult children and their parents experience for one another. International Journal of Ageing and Human Development, 67 (2), 101-127. https://doi.org/10.2190/AG.67.2.a

16. Hlebec, V., Sircelj, M. \& Mrzel, M. (2010). How to monitor intergenerational solidarity in social support networks? Teorija in praksa, 47 (6) 1127-1149.

17. Hosseinpoor, A. R., Bergen, N. \& Chatterji, S. (2013). Socio-demographic determinants of caregiving in older adults of low- and middle-income countries. Age and Ageing, 42, 330-338. https://doi.org/10.1093/ageing/afs196

18. Ikkink, K. K.,van Tilburg, T. \& Knipscheer, K. (1999). Perceived instrumental support exchanges in relationships between elderly parents and their adult children: Normative and structural explanations. Journal of Marriage and Family, 61 (4), 831-844. https://doi.org/10.2307/354006

19. Karantzas, G. C., Evans, L. \& Foddy, M. (2010). The role of attachment in current and future parent caregiving. Journal of Gerontology: Psychological Sciences, 65b (5), 573-580. https://doi.org/10.1093/geronb/gbq047

20. Kawakami, A. \& Son, J. (2015). »l don't want to be a burden«: Japanese immigrant acculturation and their attitudes toward non-family-based elder care. Ageing International, 40 (3), 262-276. https://doi.org/10.1007/s12126-015-9220-8

21. Mali, J. (2019). The method of personal planning and the implementation of services in social work with older people. Ljetopis socijalnog rada, 26 (1), 61-80. https://doi.org/10.3935/ljsr.v26i1.253

22. Mendonca, M. \& Fontaine, A. M. (2014). The role maturity of parents of emerging adult children: Validity of a parental maturity measure. Journal of Adult Developement, 21, 116-128. https://doi.org/10.1007/s10804-014-9185-y

23. Merz, E. \& Consedine, N. S. (2009). The association of family support and wellbeing in later life depends on adult attachment style. Attachment \& Human Development, 11 (2), 203-221. https://doi.org/10.1080/14616730802625185

24. Petrak, O., Despot-Lučanin, J. \& Lučanin, D. (2006). Kvaliteta starenja - neka obilježja starijeg stanovništva Istre i usporedba s drugim područjima Hrvatske. Revija za socijalnu politiku, 13 (1), 37-51. https://doi.org/10.3935/rsp.v13i1.87

25. Pillemer, K. \& Suitor, J. J. (2014). Who provides care? A prospective study of caregiving among adult siblings. The Gerontologist, 54 (4), 589-598. https://doi. org/10.1093/geront/gnt066

26. Podgorelec, S. \& Klempić, S. (2007). Starenje i neformalna skrb o starim osobama u Hrvatskoj. Migracijske i etničke teme, 23 (1-2), 111-134. 
27. Puljiz, V. (2016). Starenje stanovništva - izazov socijalne politike. Revija za socijalnu politiku, 23 (1), 81-98. https://doi.org/10.3935/rsp.v23i1.1281

28. Rusac, S. (2016). Alzheimerova bolest: Izazovi socijalnog rada. Ljetopis socijalnog rada, 23 (3), 439-461. https://doi.org/10.3935/ljsr.v23i3.129

29. Shahyad, S., Besharat, M. A., Asadi, M., Shir Alipour, A. \& Miri, M. (2011). The relation of attachment and perceived social support with life satisfaction: Structural equation model. Procedia Social and Behavioural Sciences, 15, 952-956. https:// doi.org/10.1016/j.sbspro.2011.03.219

30. Shen, Y. \& Yeatts, D. E. (2013). Social support and life satisfaction among older adults in China: Family-based support versus community-based support. International Journal of Ageing and Human Development, 77 (3), 189-209. https://doi. org/10.2190/AG.77.3.b

31. Silverstein, M., Conroy, S. J., Wang, H., Giarrusso, R. \& Bengtson, L. V. (2002). Reciprocity in parent-child relations over the adult life course. Journal of Gerontology: Social Sciences, 57 (1), S3-S13. https://doi.org/10.1093/geronb/57.1.S3

32. Silverstein, M., Gans, D. \& Yang F. M. (2006). Intergenerational support to aging parents: The role of norms and needs. Journal of Family Issues, 27, 1068-1084. https://doi.org/10.1177/0192513X06288120

33. Strmota, M. (2017). Stanovništvo 50+ u ulozi pružatelja i primatelja neformalne skrbi u Hrvatskoj. Revija za socijalnu politiku, 24 (1), 1-18. https://doi.org/10.3935/ rsp.v24i1.1368

34. Suitor, J. J., Gilligan, M., Johnson, K. \& Pillemer, K. (2014). How widowhood shapes adult children's responses to mothers' preferences for care. Journals of Gerontology, Series B: Psychological Sciences and Social Sciences, 69 (1), 95-102. https:// doi.org/10.1093/geronb/gbt062

35. van der Pas, S., van Tilburg, T. \& Knipscheer, K. (2005). Measuring older adults' filial responsibility expectations: Exploring the application of a vignette technique and an item scale. Educational and Psychological Measurement, 65 (6), 1026-1045. https://doi.org/10.1177/0013164405278559

36. Vuić, I. \& Rusac, S. (2017). Financijsko zlostavljanje starijih osoba. Revija za socijalnu politiku. 24 (3), 321-342. https://doi.org/10.3935/rsp.v24i3.1423

37. Wenzel, K. A. \& Poynter, D. (2014). »'m mother! I can take care of myself!«: A contrapuntal analysis of older parents' relational talk with their adult children. Southern Communication Journal, 79 (2), 147-170. https://doi.org/10.1080/10417 94X.2014.881540

38. World Health Organization (2015). World report on ageing and health. Luxembourg: WHO.

39. Žganec, N., Rusac, S. \& Laklija, M. (2008). Trendovi u skrbi za osobe starije životne dobi u Republici Hrvatskoj i u zemljama Europske Unije. Revija za socijalnu politiku, 15 (2), 171-188. https://doi.org/10.3935/rsp.v15i2.743

\section{8 članci}


Katarina Banov

Family care association Rijeka

Sanja Smojver-Ažić

University of Rijeka

Faculty of humanities and social sciences

Department of psychology

\title{
FILIAL CAREGIVING EXPECTATIONS FROM THE PERSPECTIVE OF ADULT CHILDREN AND PARENTS
}

\begin{abstract}
Intergenerational filial solidarity, or instrumental, emotional or health-oriented care for parents by their adult children, is a dominant form of elderly care. Parents and adult children may have different views of responsibility in the filial care for the elderly. Both elderly parents and their children value the safety and the preservation of parents' health. However, other forms of elderly care may be preferred when both sides appreciate the autonomy and maintain quality long-term relationships. In families that have not yet experienced an increased parental need for care, it is possible to study the expectations of future filial caregiving, which is a valuable source of information for intervention planning. This research aims to describe the filial caregiving expectations using two independent samples: 234 adult children, potential care providers, and 152 elderly parents, potential recipients of support. A "Scale of Filial Caregiving Expectations" has been constructed for the purpose of this research. Differences in the expression of filial care expectations have been found in different filial caregiving examples, as well as in expected accommodation arrangements. Differences in the expectations of future reception or provision of family caregiving have been found depending on examined socio-demographic characteristics - caregiver's gender, number of underage children in the family and distance from their parents' place of residence. The implications for further research and social practice are discussed.
\end{abstract}

Key words: self-report scale of caregiving expectations, intergenerational solidarity, filial caregiving.

\section{(1) (9)}

Međunarodna licenca / International License:

Creative Commons Attribution-NonCommercial-NoDerivatives 4.0. 
